\title{
A Pesquisa Pública e a Indústria Sementeira nos Segmentos de Sementes de Soja e Milho Híbrido no Brasil*
}

\author{
Marcos Paulo Fuck \\ Doutorando do Departamento de Política Científica e Tecnológica/DPCT, \\ Instituto de Geociências, Unicamp

\section{Maria Beatriz Bonacelli} \\ Professora do Departamento de Política Científica e Tecnológica/DPCT, \\ Instituto de Geociências, Unicamp e Coordenadora do Grupo de Estudos \\ sobre Organização da Pesquisa e da Inovação (GEOPI/DPCT)
}

\section{RESUMO}

Os últimos anos têm sido marcados por diversas mudanças na organização da pesquisa agrícola. Neste novo momento, as Instituiçōes Públicas de Pesquisa Agrícola (IPPAs) estão perdendo o espaço ocupado durante a Revolução Verde. Atualmente, em diversos países do mundo, as empresas transnacionais têm sido as principais executoras de pesquisas sobre biotecnologia agrícola e, conseqüentemente, têm ampliado sua participação no mercado de sementes de importantes culturas agrícolas. Porém, entende-se que sem o fortalecimento das instituições de pesquisa locais, os países em desenvolvimento podem vir a ser meros receptores passivos de tecnologias desenvolvidas por tais empresas, não aproveitando as oportunidades a serem exploradas no campo da biotecnologia e não conseguindo se contrapor às estratégias das

\footnotetext{
* Os autores agradecem a leitura atenta e os comentários dos pareceristas anônimos, os quais, acredita-se, permitiram maior clareza ao artigo.
} 
empresas transnacionais. No caso brasileiro, a forma de atuação da Empresa Brasileira de Pesquisa Agropecuária (Embrapa) é um bom exemplo de como um IPPA pode participar de modo competitivo desta nova era da pesquisa agrícola.

PalaVras-Chave | Organização da Pesquisa Agrícola; Intervenção Estratégica; Relaçōes Público-Privado; Lei de Proteção de Cultivares; Biotecnologia

Códigos Jel | O32; O33; O34; Q13; Q58

\section{ABSTRACT}

The organization of agricultural research has gone through several changes in the past few years. At present, the Public Institutions for Agricultural Research (IPPAs) are losing the position once occupied during the Green Revolution. Nowadays, in various countries of the world, the multinational firms have been doing most of the research in agricultural biotechnology and, consequently, they have expanded their participation in the seed market of important agricultural cultures. It is believed that unless the local research institutions are not strengthened, developing countries may possibly come to be merely passive receptors of technologies developed by those companies. Therefore, they should take advantage of the opportunities to be explored in the biotechnology area and, in that way, be in a position to compete with the multinational firms. In Brazil's case, the way the Empresa Brasileira de Pesquisa Agropecuária (Embrapa) participates is a good example of how an IPPA can be competitive in this new era of agricultural research.

KEYWORDS | Agricultural Research Organization, Strategic Intervention, PublicPrivate Relationships, Cultivation Protection Laws, Biotechnology

JEL-CODES I O32; O33; O34; Q13; Q58 


\section{Introdução}

Nos últimos anos observam-se diversas mudanças na forma de organização da pesquisa agropecuária e também no mercado de sementes no Brasil e no Mundo. Enquanto durante a Revolução Verde, ocorrida nas décadas de 50 e 60 do século passado, o setor público era o principal agente participante do processo de pesquisa agrícola, atualmente é o setor privado o principal agente, motivado pela expectativa de ganhos financeiros decorrentes das novas tecnologias. Porém, entende-se que sem o fortalecimento das instituições de pesquisa locais, os países em desenvolvimento podem vir a ser meros receptores passivos de tecnologias desenvolvidas pelas empresas transnacionais, não aproveitando as oportunidades a serem exploradas no campo da biotecnologia.

Para realizar esta discussão sobre a importância das Instituições Públicas de Pesquisa Agrícola (IPPAs) nos países em desenvolvimento, utilizar-se-á o caso da Empresa Brasileira de Pesquisa Agropecuária (Embrapa) e de sua forma de atuação nos mercados de soja e milho híbrido. Para o desenvolvimento de suas atividades de P \&D agropecuária, a Embrapa realiza arranjos institucionais com outros atores relevantes (iniciativa privada, organizaçóes de produtores, fundações de pesquisa, outras instituições congêneres, etc.). As parcerias com diferentes agentes do mercado de sementes podem, como no caso da União dos Produtores de Sementes de Milho da Pesquisa Nacional (Unimilho), das fundações de produtores e da Monsanto, conferir condições para intervenção no mercado de forma a ampliar impactos positivos para os usuários do setor agrícola, contribuindo para a legitimação da Embrapa como Instituição Pública de Pesquisa e dando às relações público-privado uma nova conotação (na pesquisa e no mercado de sementes).

Neste artigo será discutida a forma como a Embrapa realiza a pesquisa de novas variedades de soja e milho híbrido e também a forma como a Instituição intervém no mercado de sementes destas culturas. Em termos de volume, trata-se das duas principais culturas cultivadas no Brasil. Os números oficiais referentes à produção nacional de grãos na safra 2004/05 revelam que a soja foi responsável por cerca de $45 \%$ de um total de 113,9 milhôes de toneladas colhidas no País, ao passo que a produção nacional de milho respondeu por cerca de $31 \%$ do total. 
A importância desses dois grãos justifica a intervenção estratégica por parte da Embrapa. Até mesmo porque o Brasil possui um histórico de pesquisa pública e os avanços recentes da biotecnologia oferecem possibilidades que não podem ser descartadas. Sobre esse último ponto, vale destacar que, em nível mundial, essas duas culturas são as mais significativas em termos da área global ocupada com Organismos Geneticamente Modificados (OGMs). Segundo James (2005), na safra 2005, a soja transgênica ocupou 54,4 milhões de hectares ( $60 \%$ da área global com OGMs) e o milho transgênico foi plantado em 21,2 milhões de hectares (24\% da área global).

Esses números revelam a importância da Embrapa participar de forma ativa nesses mercados, inclusive no desenvolvimento de variedades geneticamente modificadas, não só ampliando a concorrência, mas também ocupando importantes espaços estratégicos, dada a importância dessas culturas para agricultura nacional.

\section{A organização da pesquisa agrícola}

Em alguns países em desenvolvimento, a pesquisa agrícola desenvolvida em institutos de pesquisa teve início no período entre as últimas décadas do século XIX e as primeiras décadas do século passado. No geral, o foco inicial destas pesquisas era em relação às culturas voltadas ao mercado externo. No caso brasileiro, País com forte tradição na pesquisa agropecuária, o Governo Federal criou vários institutos de pesquisa agrícola no final do século XIX e início do século passado que concentraram suas atividades em culturas de exportação, como café e cana-de-açúcar. Um exemplo disso foi a criação do Instituto Agronômico (IAC, fundado em 1887 e depois transferido ao governo de São Paulo, em 1891) (Beintema et al., 2001).

Nas décadas de 1950 e 1960, implementou-se, em diversos países, a Revolução Verde. Esse fenômeno compreendeu o emprego de novas tecnologias, tais como o uso de herbicidas, fertilizantes e variedades de plantas com maior resposta à aplicação de fertilizantes (em um primeiro momento, arroz, trigo e milho, e, posteriormente, soja), assim como de modernas máquinas e equipamentos. $\mathrm{O}$ estímulo à organização institucional centralizada e concentradora de recursos foi um elemento indissociável desse 
movimento de difusão do padrão tecnológico produtivista (Bonny \& Daucé, 1989; Petit \& Barghouti, 1992), que definia como problema relevante central o controle das variáveis técnicas para a obtenção da maior produção possível por unidade de área (ou de trabalho).

Segundo Salles-Filho (1993), três grandes características desse padrão tecnológico produtivista são: $i$ ) as heterogeneidades e complementaridades existentes entre os diversos insumos e técnicas; ii) a redefinição da inserção da agricultura na economia, promovendo a integração com segmentos industriais (a montante e a jusante) e comerciais (interno e externo); e iii) a busca incessante de aumentos de produtividade da terra e do trabalho. Essas três grandes características podem ser identificadas como o paradigma social dominante, que orientou a lógica de ação dos agentes intervenientes no processo de inovação da agropecuária.

Durante os anos 1960, diversos institutos internacionais de pesquisa agrícola foram instalados em todo o mundo, visando a ampliação da produção de alimentos via sementes melhoradas. Em 1959 foi criado o Instituto Internacional de Pesquisa de Arroz (IRRI), nas Filipinas, por meio de acordo entre as fundações Ford e Rockefeller. Em 1963 foi estabelecido, no México, o Centro Internacional para Melhoramento de Milho e Trigo (CIMMYT). Nesse período, estas duas instituições colaboraram na criação do Instituto Internacional para Agricultura Tropical (IITA), na Nigéria, e do Centro Internacional para Agricultura Tropical (CIAT), na Colômbia. Em 1971 foi criado o Grupo Consultivo para Pesquisa Agrícola Internacional (CGIAR), que incluía membros do Banco Mundial, da Organização para Alimentação e Agricultura (FAO) ${ }^{1}$ e do Programa das Nações Unidas para o Desenvolvimento (PNUD), como patrocinadores, e nove representantes de governos nacionais, dois bancos regionais e três fundações (Mello, 1995; Hayami \& Ruttan, 1988).

Com o patrocínio do CGIAR, o sistema internacional de pesquisa cresceu rapidamente, contribuindo para o crescimento da produção agrícola nos países em desenvolvimento. A área plantada com as novas variedades de trigo e arroz, desenvolvidas inicialmente no CIMMYT e IRRI, adaptadas e espalhadas pelos

\footnotetext{
1 A FAO foi criada no final da Segunda Guerra Mundial, com sede em Roma, com as funções de um ministério de alimentação e agricultura para todo o globo. A FAO - por meio de suas atividades de assistência técnica, educacional e comunicação regional e de organização - fez contribuições significativas para o desenvolvimento da capacidade nacional de pesquisa na agricultura (Hayami \& Ruttan, 1988).
} 
sistemas de pesquisa e extensão agrícolas nacionais, expandiu-se rapidamente por diferentes regiōes. Contudo, o mesmo não aconteceu com a pesquisa realizada nos demais centros. Isso pelo fato de que os programas de trigo e arroz puderam basear-se no grande estoque de resultados de pesquisa das regiōes temperadas, enquanto os outros centros trabalhavam com produtos agrícolas e sistemas de produção específicos dos trópicos, para os quais não havia reserva comparável de conhecimento científico e técnico. Em consequiência, o fluxo de tecnologia entre os institutos e seu impacto sobre a produção agrícola foram mais lentos (Hayami \& Ruttan, 1988).

No caso latino-americano, a adoção do modelo institucional centralizado, em substituição ao chamado modelo difuso, levou à criação, em boa parte dos países da região, de Sistemas Nacionais de Pesquisa para a Agricultura (INIAS) que deveriam ser capazes de coordenar e concentrar os recursos então considerados "escassos" (Trigo et al., 1985; Ruttan, 1983): INTA argentino (1957), INIAP do Equador (1959), complexo CONIA-FONIAP da Venezuela (entre 1959 e 1961), INIA do México (1960), SIPA do Peru (1963), ICA da Colômbia (1963) e INIA do Chile (1964). O objetivo era criar uma infraestrutura em condições de adaptação das tecnologias disponíveis no âmbito internacional, objetivando a transposição para esses países. ${ }^{2}$ Essas instituições também foram responsáveis pelo processo de corrdenação da pesquisa agrícola em nível nacional como forma de melhorar a eficiência no uso dos fundos públicos - importante fonte de financiamentos dos INIAs.

O Brasil não se enquadra neste processo, centralizando sua pesquisa só a partir de 1973, com a criação da Embrapa. Para Piñero e Trigo (1985), a situação do Brasil é atípica. Diferente dos países citados acima, quando da criação da Embrapa, não houve a incorporação da pesquisa e da extensão numa mesma instituição. Além disso, a Embrapa também coordenava os esforços de pesquisa nos planos nacional e estadual, e havia previsão de participação do setor privado. Estas especificidades fazem com que os autores questionem se a Embrapa é uma extensão do modelo institucional dos anos

2 Conforme explica Salles-Filho (1995), na maioria desses casos, percebe-se uma idéia de desenvolvimento agrícola de inspiração "schultziana", que preconizava a oferta de tecnologia abundante e barata (ou melhor, tornada barata via subsídios) como o principal meio para se promover o desenvolvimento agrícola em países em desenvolvimento (Schultz, 1965). Nessa ótica, as instituições de pesquisa deveriam fechar o elo fundamental do mecanismo econômico de indução da inovação, viabilizando novas e fundamentais "correntes de renda" na agricultura (Hayami \& Ruttan, 1988). Contudo, deve-se ressaltar que esse modelo viabilizava a difusão de tecnologia pela pesquisa adaptativa, generalizando um padrão tecnológico originado, principalmente, nos Estados Unidos. 
1960 ou se marca o início de um novo modelo que modifica o papel do Estado e as relações entre os setores público e privado no processo de geração e transferência de tecnologia.

No decorrer dos anos 1980, questôes relativas à política ambiental, à constituição de novas arenas do comércio internacional, às transformações nas políticas agrícolas, ao surgimento de novas áreas do conhecimento com relação direta com a tecnologia agrícola (a biologia molecular, por exemplo), ao deslocamento de certas funções do Estado, entre outras, colocaram elementos que não encontraram solução no paradigma vigente. Observou-se um processo de esgotamento do padrão tecnológico produtivista, o que também teve impacto no paradigma institucional da pesquisa agrícola, levando a um reposicionamento das IPPAs no cenário inovativo (Carvalho, 1996). Trata-se de um esgotamento de alcance global e de abrangência integral (Salles-Filho, 1995).

Para Salles-Filho et al. (1997), observa-se uma reconfiguração da relação público-privado, hoje muito mais complexa que aquela que predominou nas últimas décadas, porque não mais baseada em definições ad hoc do tipo: às instituições públicas cabe desenvolver bens públicos e às instituições privadas bens privados. "Tal disjuntiva, outrora central para a definição do investimento público em pesquisa agrícola, hoje desfaz-se frente a uma realidade muito mais complexa e dinâmica, na qual há uma demanda crescente e extremamente diversificada por habilidades especificas para o desenvolvimento cientifico $e$ tecnológico" (p.192).

Este novo contexto evidencia a necessidade da realização de práticas de monitoramento dos mercados e antenagem tecnológica por parte das IPPAs. A utilização destas práticas pode favorecer a busca de complementaridade no processo de pesquisa. Identificando suas competências e buscando aquelas que não possuem, as instituições podem se beneficiar com a formação de redes de pesquisa, hoje o meio mais eficaz para lidar com projetos tecnológicos complexos em ambientes de rápida mudança, como no caso da biotecnologia (Fuck, 2005).

\section{0 novo ambiente para a pesquisa agrícola}

Como dito, diversos acontecimentos têm influenciado na organização da pesquisa agrícola. Conforme FAO (2004), diferente das pesquisas que impulsio- 
naram a Revolução Verde, parte significativa das pesquisas sobre biotecnologia agrícola e quase todas as atividades de comercialização estão sendo realizadas por empresas privadas, com sede em países industrializados. Isto representa uma mudança radical em relação à Revolução Verde, na qual o setor público desempenhou um importante papel na pesquisa e na difusão de tecnologias. Essa mudança tem importantes conseqüências em relação à forma como se realiza a pesquisa, aos tipos de tecnologias que são elaboradas e ao modo como se difundem essas tecnologias. O predomínio do setor privado nas pesquisas com biotecnologia agrícola pode fazer com que os produtores dos países em desenvolvimento, sobretudo os agricultores pobres, não tenham acesso aos seus benefícios.

Ainda conforme FAO (2004), não estão claras as possibilidades dos sistemas públicos de pesquisa se beneficiarem do trabalho desenvolvido pelas empresas transnacionais. Além disso, os programas de pesquisa do setor público, na maior parte das vezes, ficam restritos às fronteiras nacionais, o que reduz os benefícios das inovações tecnológicas entre zonas agroclimáticas similares (de diferentes países). O sistema de intercâmbio de germoplasma do CGIAR tem atenuado o problema no caso de vários cultivos importantes, mas não está claro se funcionará também para os produtos obtidos por meios biotecnológicos e os cultivos transgênicos, tendo em conta os direitos de propriedade a que estão sujeitas as tecnologias.

Em vista disto, formas alternativas de cooperação têm sido realizadas. Um exemplo pode ser dado pelo PIPRA (Public Intellectual Property Resource for Agriculture). Trata-se de uma associação de diversas universidades norteamericanas e Institutos de pesquisa agrícola. O PIPRA visa superar os obstáculos ao desenvolvimento das pesquisas em biotecnologia por três meios: a) um levantamento de tecnologias patenteadas pelo setor público de vários países, criando banco de dados acessíveis aos pesquisadores; $b$ ) elaboração de "estudos de caso" que mostrem como é possível utilizar tecnologias sob a propriedade intelectual de organizaçóes públicas para realizar pesquisas em biotecnologia; e $c$ ) incentivar redes de colaboração, a atividade mais importante da Associação (Dal Poz et al., 2004). Vale destacar que a possibilidade deste arranjo ser bem-sucedido cresce com a importância das organizaçôes que dele participam.

Para FAO (2004) e Traxler (2003), a capacidade requerida para utilizar 
a tecnologia difere da capacidade necessária para gerar tecnologia. Em países como Argentina, África do Sul e México, os OGMs que estão sendo utilizados foram desenvolvidos pela Monsanto para o mercado dos Estados Unidos. Apenas foram desenvolvidas pesquisas de modo a adaptar as variedades locais aos genes transgênicos. Porém, existem numerosos países em desenvolvimento que não estão em condições de realizar nem sequer esse tipo de pesquisa adaptativa.

Em relação ao CGIAR, Traxler (2003) considera que, dado o baixo nível de investimentos que vem sendo realizado em biotecnologia, é improvável que a Instituição se torne uma expressiva fornecedora de pesquisas em biotecnologia para os países em desenvolvimento. Outra possibilidade institucional pode ocorrer por intermédio de países com grandes Sistemas Nacionais de Pesquisa Agrícola, como China, Índia e Brasil. Esses países podem tornar-se fornecedores de tecnologias para países menores. Segundo o autor, não há nenhum indício de que o setor público de nenhum outro país em desenvolvimento passe a ser um participante importante na oferta de pesquisas em biotecnologia. Porém, a difusão de tecnologia entre os países em desenvolvimento é pouco expressiva, uma vez que nenhum outro país se beneficiou das descobertas biotecnológicas realizadas na China e a aprovação para uso comercial de OGMs no Brasil e na Índia é recente.

Ainda de acordo com os mesmos trabalhos, a falta de arranjos institucionais para compartilhar a propriedade intelectual é um grande obstáculo a ser superado para a transferência de tecnologias de uma instituição nacional do setor público a outra. Atualmente, à exceção do germoplasma que se está sendo compartilhado nas redes do CGIAR, é muito escasso o intercâmbio internacional de tecnologia entre instituições do setor público. Em relação aos investimentos em biotecnologia por parte do setor privado nos países em desenvolvimento, Traxler (2003) destaca a existência de três grandes obstáculos: os elevados custos de transação para a entrada em cada mercado; as dificuldades em relação à proteção da propriedade intelectual; e o limitado mercado de sementes da maioria desses países.

FAO (2004) e Traxler (2003) consideram uma situação hipotética na qual o setor privado poderia passar a ser uma fonte mais viável de inovaçôes biotecnológicas para os países em desenvolvimento. Essa situação seria aquela em que os países em desenvolvimento que representam um grande mercado, 
por exemplo, Brasil, China, Índia e África do Sul, passem a ser mais "favoráveis aos OGMs". Se estes países dispuserem de leis estáveis, regimes de propriedade intelectual e os consumidores aceitarem alimentos geneticamente modificados, o setor privado provavelmente efetuaria investimentos substanciais em P\&D para a criação de produtos geneticamente modificados. Os quatro países mencionados, conjuntamente, contam com um mercado de sementes de aproximadamente US\$ 5 bilhões. Ainda segundo os autores, os produtos desenvolvidos para estes mercados estariam à disposição dos países vizinhos que tenham estabelecido regulamentação relativa à biossegurança e uma capacidade de aplicação dos direitos de propriedade intelectual.

Porém, conforme destaca a própria FAO (2004), os países que melhor aproveitaram as oportunidades oferecidas pela Revolução Verde foram aqueles que tinham, ou criaram rapidamente, uma ampla capacidade nacional de pesquisa agrícola. Naquele momento, havia interesse na rápida difusão das tecnologias. Por exemplo, diversos institutos internacionais de pesquisa agrícola foram instalados em várias regiōes do mundo, com o apoio das Fundações Ford e Rockefeller. Ocorreu também intercâmbio entre universidades norte-americanas e brasileiras. Hoje o contexto é diferente com o predomínio de empresas transnacionais na oferta das novas tecnologias. Os institutos de pesquisa agrícola dos países menos desenvolvidos estão perdendo a importância ocupada no passado.

Para Seiler (1998), se não houver uma correção no modo como a biotecnologia está sendo modelada e não ocorrerem intervenções das instituições públicas de pesquisa para contrabalançar os interesses privados na agenda da pesquisa, serão "confirmados os temores dos críticos de que a 'biorrevolução' vai repetir os resultados ambivalentes da Revolução Verde" (p.62). Diante dessas discussões, entende-se que sem o fortalecimento das instituições de pesquisa locais, os países em desenvolvimento, dada a grande heterogeneidade que os caracteriza, podem vir a ser meros receptores passivos de tecnologias desenvolvidas pelas empresas transnacionais. Entende-se que os países em desenvolvimento poderiam ter um melhor benefício da biotecnologia com o fortalecimento das estruturas de pesquisa locais, explorando as complementaridades entre o setor público e privado (nacional ou não), e com isso ter um espaço de criação mais amplo em relação às alternativas tecnológicas (Fuck, 2005). 
No caso brasileiro, a Embrapa tem buscado se capacitar nestas novas tecnologias para o desenvolvimento de variedades geneticamente modificadas. Nos segmentos de soja e milho híbrido, que serão abordados neste artigo, além das pesquisas para o desenvolvimento de novas variedades, a Instituição tem realizado parcerias com as empresas privadas, tanto na pesquisa como no mercado de sementes. Isto revela uma forma interessante de articulação público-privado. Dado que estes segmentos que têm atraído grandes investimentos privados, sobretudo por parte das empresas transnacionais, entende-se que esta forma de atuação possibilita que a instituição pública tenha melhores condições de intervir nos mercados em que atua.

Além disso, estes dois segmentos são os mais representativos dentre os OGMs cultivados no mundo. Conforme James (2005), a soja foi a principal lavoura geneticamente modificada em 2005, ocupando 54,4 milhões de hectares (60\% da área global ocupada com OGMs), seguida pelo milho $(21,2$ milhões de hectares com $24 \%$ da área global com OGMs), pelo algodão ( 9,8 milhões hectares com $11 \%$ da área global com OGMs) e pela canola (4,6 milhões de hectares com 5\% da área global com OGMs). Em 2005, da área total plantada com lavouras geneticamente modificadas, $71 \%$ referiam-se a variedades com tolerância à herbicida, $18 \%$ a variedades resistentes a insetos e $11 \%$ a variedades com as duas funções. Deste modo, observa-se então que, até o momento, a difusão desta nova tecnologia está concentrada em cultivos geneticamente modificados com atributos agronômicos e está focada em poucas culturas agrícolas.

Conforme Seiler (1998), as novas biotécnicas já oferecem muitas possibilidades de minorar problemas prementes no Terceiro Mundo, principalmente sob o princípio da engenharia genética, como por meio da rápida multiplicação de material vegetal saudável (isento de vírus) ou da adaptação melhorada das safras ao seu meio ambiente geoclimático específico. Para tanto, as IPPAs devem ter uma postura mais ativa no desenvolvimento dessas novas tecnologias. Novamente usando o exemplo da Embrapa, observa-se que a Instituição tem produtos, além da soja transgênica, que podem ser viáveis em pequenas propriedades e que, por razões de mercado, não são de interesse das grandes corporações, como o feijão tolerante ao vírus do mosaico dourado, o mamão resistente ao vírus da mancha anelar, o milho de elevada qualidade nutricional, algumas 
variedades de batatas resistentes a certos vírus, etc. Assim, é relevante que as IPPAs se capacitem de modo a melhor se apropriar e beneficiar da biotecnologia, tanto nas culturas em que a iniciativa privada não tem interesse em investir, como naquelas culturas que envolvem maior volume de recursos financeiros, nas quais a iniciativa privada é mais presente. Assim as IPPAs conseguem contrabalancear as estratégias dessas empresas e ampliar a concorrência nesses mercados, favorecendo as pequenas sementeiras e os produtores (Fuck, 2005).

\section{A formação do mercado de sementes de soja}

Segundo Wilkinson e Castelli (2000), na década de 1970 ocorreu a criação de centros de pesquisa e experimentação privados no Brasil, cujo objetivo principal era o melhoramento vegetal. Uma das empresas privadas pioneiras na pesquisa de soja foi a Francisco Terasawa (FT), fundada no final da década de 1960, em Ponta Grossa (PR). As primeiras variedades de soja liberadas pela empresa, Cristalina e FT, foram de grande impacto no Paraná e na região Centro-Oeste. Conforme Santini (2002), ao longo da década de 1980, suas cultivares de soja passaram a predominar do Sul ao Centro-Oeste do País.

Em 1973, foi criado o Centro de Pesquisa e Experimentação da Fecotrigo (Federação das Cooperativas de Trigo e Soja do Rio Grande do Sul Ltda.), com objetivo de gerar e difundir cultivares de trigo e soja adaptadas ao Rio Grande do Sul. As variedades da Fecotrigo tiveram razoável difusão no Estado, mas foram pouco difundidas no resto do País (Wilkinson \& Castelli, 2000). Na década de 1970, a Organização das Cooperativas do Paraná (Ocepar) criou também um centro de pesquisa privado com o objetivo de melhoramento vegetal, visando a difusão de variedades próprias às cooperativas filiadas à Organização. Em 1995, a assembléia geral da Ocepar decidiu transformar o seu departamento de pesquisa numa cooperativa central agropecuária, que recebeu o nome de Cooperativa Central de Pesquisa Agrícola (Coodetec) (Massola, 2002).

Conforme Silveira (1985), no mercado de sementes de soja a característica comum é o grande número de cultivares disponíveis aos agricultores e a participação das cooperativas em quase todas as etapas da produção de sementes. Em todas as culturas de plantas autógamas (como a soja), a atuação do setor privado na geração de cultivares é limitada do ponto de vista da lucratividade 
exigida pela indústria de sementes. ${ }^{3} \mathrm{O}$ interesse de cooperativas pela introdução de novos cultivares e realização de ensaios somente pode ser entendido como uma busca de ampliação da influência das cooperativas junto aos agricultores, que permite à mesma estabelecer uma ampla rede de serviços à montante $\mathrm{e}$ jusante da produção. Este fato, todavia, confirma a importância fundamental do setor público na pesquisa e melhoramento.

Em 1975 foi criada a Embrapa Soja ${ }^{4}$ (denominação recente para o Centro Nacional de Pesquisa de Soja - CNPS) em Londrina (PR). Atualmente, sua missão é "viabilizar soluçôes tecnológicas competitivas para o desenvolvimento sustentável do agronegócio da soja, por meio da geração, adaptação e transferência de conhecimentos e tecnologias, em benefício da sociedade" (www.cnpso.gov.br, acesso em 1/2/2006). As competências básicas da Embrapa Soja incluem a pesquisa, o desenvolvimento e a transferência de tecnologia nas culturas de soja e girassol. Inclui-se ainda em sua competência o apoio a outras unidades de pesquisa da Embrapa, como a Embrapa Trigo, a Embrapa Arroz e Feijão e a Embrapa Milho e Sorgo, para o desenvolvimento de programas específicos para o Estado do Paraná, onde está localizada. Ao longo de sua história, o programa de pesquisa da Embrapa Soja tem contribuído para a expansão da fronteira agrícola em direção às regiões do cerrado do Brasil.

A unidade realiza pesquisas com soja convencional, orgânica e transgênica. Neste sentido, vale destacar que em 2003 foi inaugurada a Unidade de Beneficiamento de Sementes visando beneficiar sementes de soja transgênica com fins de pesquisa. De modo geral, no mercado de sementes de soja, a pesquisa pública, juntamente com as cooperativas privadas de caráter coletivo, "tiveram e ainda têm um peso muito importante nos programas de melhoramento de cultivares, que são comercializados por meio de sistemas de parcerias com algumas empresas nacionais privadas" (Santini, 2002:86).

Após a aprovação da Lei de Proteção aos Cultivares, em 1997, que garante a propriedade intelectual dos cultivares e obriga os produtores a pagarem royalties e taxas de utilização da tecnologia, observou-se a entrada de

3 Neste casos é bastante comum por parte dos produtores o reaproveitamento de parte da safra como semente na safra seguinte, o que traz limitações claras para a apropriabilidade de investimentos em P\&D na indústria de sementes (Lazzarini \& Nunes, 1998).

4 A Embrapa é um sistema formado por 11 Unidades Centrais, localizadas no edifício-sede, e por 40 Unidades Descentralizadas distribuídas nas diversas regiões do Brasil. 
empresas transnacionais no mercado de sementes, inclusive no de soja. $\mathrm{Na}$ década de 1990, várias empresas nacionais de pequeno ou grande porte foram compradas ou absorvidas pelas transnacionais, principalmente aquelas detentoras de tecnologia de ponta na área de biotecnologia (Wilkinson \& Castelli, 2000). A entrada da Monsanto no segmento de soja ocorreu em 1997, com a aquisição da empresa FT Sementes, proporcionando à empresa um importante programa de melhoramento.

Dentre as empresas nacionais dedicadas à produção de variedades de soja, as principais aquisiçôes realizadas pelas transnacionais foram as seguintes: a Monsanto comprou a divisão de soja da FT Sementes e da Sementes Hatã; a Agr-Evo adquiriu a Sementes Ribeiral, produtora de sementes de soja e milho; e a $\mathrm{Du}$ Pont adquiriu as empresas Pioneer, produtora de sementes de soja e milho, e a Dois Marcos Melhoramentos, produtora de sementes de soja. O objetivo das empresas transnacionais agroquímicas ao realizarem a aquisição dessas sementeiras é garantir uma estratégia conjunta de testes e difusão de sementes "engenheiradas" que aumentem a participação dos herbicidas comercializados pela empresa que fez a aquisição (Silveira \& Salles-Filho, 1998).

Comentando as aquisiçôes realizadas pelas transnacionais, Wilkinson e Castelli (2000) explicam que as inovaçôes vegetais (cultivares vegetais), diferentes das inovações industriais, devem adaptar-se às condições edafoclimáticas e ecológicas nas quais serão introduzidas. Portanto, trata-se de um tipo de invenção que não pode ser transferida de seu país para o resto do mundo sem modificações e adaptações subseqüentes. Nesse sentido, as empresas transnacionais detinham o know how e os genes de interesse econômico para introduzir na criação dos cultivos transgênicos, mas não contavam com o germoplasma de cultivares adaptados aos diferentes ambientes agrícolas dos diversos países.

A partir de fusões e aquisições de sementeiras nacionais, as transnacionais agroquímicas vêm se utilizando de licenciamentos, integração e colaboração no desenvolvimento de pesquisas conjuntas com outras empresas, como importantes estratégias empresariais (Santini, 2002). A existência de ativos complementares entre a área química e o setor de sementes permite às adquirentes explorar de maneira efetiva algumas vantagens competitivas, como a marca e a tecnologia, das sementeiras adquiridas. A sustentação das posições competitivas está relacionada, em primeiro lugar, às estratégias de 
integração e diversificação das empresas e, em segundo, à realização de contratos e parcerias tecnológicas.

Conforme Santini e Paulillo (2003) e Santini (2002), as empresas originárias do ramo químico, que iniciaram o processo de diversificação em direção à indústria de sementes, como a Monsanto, Syngenta e Du Pont, estão adotando estratégias ofensivas, uma vez que investem em novas atividades de P\&D e desenvolvem novas tecnologias na área da moderna biotecnologia. Outras empresas estão adotando estratégias defensivas, como a Dow Agrosciences, que não vêm investindo tão fortemente em biotecnologia agrícola, aguardando a aprovação da produção dos transgênicos no Brasil. A estratégia de diversificação adotada pelas empresas Monsanto, Syngenta e Du Pont ocorre basicamente em novas áreas de mercado, porém dentro das áreas de especialização das firmas. A adoção de mecanismos de venda casada (semente e agroquímicos) decorre da utilização de tecnologias similares para a produção dos insumos na agricultura. "A busca por essas habilidades específicas (complementaridades) faz com que as empresas passem a manter grandes projetos de $P \& D$ sob forma de redes e comércios com outras empresas e instituiçôes públicas de ensino e pesquisa" (Santini \& Paulillo, 2003:26).

Segundo Scatolin et al. (2000), o mercado nacional de sementes de soja pode ser definido como um oligopólio diferenciado, no qual as barreiras à entrada estão vinculadas ao acesso ao material genético e às capacidades técnicas e financeiras requeridas para a produção e avaliação dos novos cultivares. Sendo um mercado dominado por poucos agentes, as estratégias e as formas institucionais das firmas, assim como o marco regulatório em que operam, desempenham um papel chave no seu comportamento. Dessa forma, como a Lei de Proteção aos Cultivares estabelece o pagamento de royalties para os usuários do produto, o processo de inovação passa a ser remunerado pelo mercado na medida que seu produto é comercializado, sendo esse novo modelo de regulação mais atrativo para as empresas produtoras de variedades, principalmente as transnacionais. "Com isso, as condiçôes de concorrência nesse setor se tornam mais difíceis para pequenas e médias empresas, na medida que as grandes passam a definir o patamar de investimento e a tecnologia necessários para competir" (Scatolin et al., 2000:332).

As fundações de produtores de sementes também se destacam na configuração produtiva da indústria de sementes no Brasil. Segundo Martinelli (2006), 
as fundações possuem um papel relevante no comércio e no processo de geração e difusão de inovação de novas sementes. Presentes em praticamente todas as regiôes do Brasil, exceto na Região Norte, elas têm potencial suficiente para competir em nível nacional com suas concorrentes. Scatolin et al. (2000) ressaltam a relação sistêmica existente entre a Embrapa e os multiplicadores de sementes reunidos em torno das fundações. As parcerias da Embrapa com as fundações permitem à Instituição "testar suas cultivares nas mais variadas condiçôes de solo, clima e manejo, obtendo assim informação crucial para o melhoramento das cultivares a partir dos feed-backs dos produtores dispersos em diversas regiōes do Brasil' (Scatolin et al., 2000:330). Essas parcerias permitem à Embrapa adaptar suas cultivares às diferentes regiōes produtoras, o que é fundamental em se tratando de um País com as dimensóes geográficas do Brasil. Ao transferir tecnologia para as fundações, a Embrapa pode contribuir para a sobrevivência de empresas pequenas e médias tecnologicamente dinâmicas.

Conforme apresentado em Fuck (2005) (a partir de entrevistas realizadas), nessa relação entre a Embrapa e as fundaçōes, os compromissos das fundaçōes são das seguintes ordens: 1) aporte de recursos financeiros para o custeio da pesquisa e da transferência de tecnologia e marketing das novas cultivares; 2) aporte parcial de recursos físicos (propriedades rurais) e de veículos, máquinas e equipamentos; 3) aporte parcial de recursos humanos, cuja intensidade determina o prazo da exclusividade de produção e comercialização das sementes das cultivares desenvolvidas. Outra obrigação das fundações é facilitar à Embrapa o recolhimento dos royalties alusivos à utilização das cultivares protegidas. Por outro lado, compete à Embrapa: a) alocação de populações híbridas na região de interesse de cada fundação, com vista à seleção local do germoplasma de melhor adaptação; b) alocação de pesquisador para realizar as atividades experimentais e de transferência de tecnologia, ou compartilhar das mesmas nos casos em que as fundações também alocam pesquisador(es); c) disponibilização das equipes especializadas das unidades envolvidas para treinamentos de técnicos e produtores associados às fundações e apoio às ações de transferência e marketing.

As principais fundações e instituições parceiras da Embrapa Soja, no desenvolvimento de cultivares de soja (e trigo), são os seguintes: Fundação PróSementes (RS), Fundação Meridional (PR); Fundação Vegetal (MS); Fundação Triângulo (MG); CTPA - Centro Tecnológico para Pesquisas Agropecuárias (GO); 
Fapcen - Fundação de Apoio à Pesquisa do Corredor de Exportação Norte "Irineu Alcides Bays" (MA); Fundação Centro-Oeste (MT); Fundação Bahia (BA); Epamig - Empresa de Pesquisa Agropecuária de Minas Gerais (MG); e Agência Rural - Agência Goiana de Desenvolvimento Rural e Fundiário (GO) (Embrapa, 2004).

\section{A formação do mercado de sementes de milho híbrido}

Até os anos 1960, a Agroceres, primeira companhia de sementes brasileira, criada em 1945, determinava os preços no mercado de milho híbrido, dado que quase não havia concorrência. A partir da década de 1960, algumas empresas multinacionais começaram a operar no mercado brasileiro de sementes. Em 1965 foi instalada a Sementes Cargill Ltda., com um centro de pesquisas em Campinas (SP) e uma unidade de beneficiamento em Avaré (SP). Na mesma década, em Santa Cruz do Sul (RS), estava sendo instalada a empresa norte-americana Pioneer-Hy-bred, por meio da associação com a empresa Proagro. Em 1971 ocorre a entrada das empresas Limagrain e Asgrow. No final da década de 1970 ocorre a entrada da Dekalb e da Ciba-Geigy. As transnacionais foram atraídas por políticas e legislação que regularizaram e subsidiaram o desenvolvimento de sementes, produção e comercialização (Santini, 2002; Wilkinson \& Castelli, 2000; Silveira, 1985).

Mesmo com a entrada das transnacionais, a Agroceres, dada a sua extensa rede de comercialização e à qualidade de sua equipe técnica, conseguiu enfrentar com sucesso a concorrência das transnacionais, mantendo sua participação entre $40 \%$ e $50 \%$, ocupando um espaço de produtos de médio desempenho, mas com boa aceitação entre os produtores. "A estratégia adotada pela empresa foi desenvolver e introduzir híbridos adaptados à mecanização e fortalecer a linha de pesquisa em hibridos precoces que, de acordo com suas características, permitiam diminuir os riscos climáticos" (Santini, 2002:79). A empresa diversificou suas atividades, entrando na área de praguicidas e raças de alto rendimento de suínos e aves em 1977, por intermédio de empresas mistas. Na década de 1980, a empresa iniciou novos projetos na área de biotecnologia vegetal, com a compra da Biomatrix. Contudo, em 1998, a empresa mais antiga e líder do mercado é adquirida pela Monsanto (Wilkinson \& Castelli, 2000; Santini, 2002). 
Entre 1981 e 1989, as quatro maiores empresas do segmento - Agroceres, Cargill, Braskalb e Pioneer - detiveram uma participação de $83 \%$ do mercado. No decorrer da década de 19b90, houve apenas um rearranjo das parcelas retidas pelas diferentes empresas. A partir de 1997, ocorre um processo de desnacionalização da produção no segmento de milho híbrido. Após a compra da Agroceres, a Monsanto comprou a divisão latino-americana de sementes da Cargill, vice-líder no mercado nacional de milho. Em 1998 adquiriu a Dekalb e, no começo de 1999, adquiriu também a Braskalb (empresa de capital nacional que era representante exclusiva no país da tecnologia da Dekalb). A Du Pont entrou na área de sementes comprando a Pioneer Hi-Bred Internacional, maior produtora mundial deste insumo. Já a Dow Chemical adquiriu as paulistas Dinamilho da Carol (Cooperativa dos Agricultores da Região de Orlândia), a Híbridos Colorado e a divisão de milho da Sementes Hatã e da FT Biogenética (Santini, 2002; Wilkinson \& Castelli, 2000).

Em 1998, a Novartis - líder no mercado de defensivos - anunciou a formação do Novartis Agricultural Discovery Institute (NADI) (em La Jolla/Califórnia), um dos maiores centros de pesquisa dedicados à $\mathrm{P} \& D$ do genoma agrícola. Em 2000, a Novartis Agribusiness e a Zeneca agrícola se fundem, formando a Syngenta. Em 2002, foi efetivada a incorporação da empresa franco-alemã Aventis CropSciences (então AgrEvo) pela alemã Bayer AG, consolidando-se a empresa Bayer Crop Science. No Brasil, a aposta da empresa é na área de defensivos agrícolas, objetivando sair à frende da Syngenta, líder no País e no mundo em vendas de defensivos agrícolas (Santini, 2002; Wilkinson \& Castelli, 2000).

Em relação à pesquisa pública, em 1976 foi implantada a Embrapa Milho e Sorgo (denominação recente para o Centro Nacional de Pesquisa de Milho e Sorgo - CNPMS), aproveitando a infra-estrutura existente do então Instituto de Pesquisa e Experimentação Agropecuária do Centro-Oeste (IPEACO). Situada em Sete Lagoas (MG), a Embrapa Milho e Sorgo desenvolve pesquisas com as culturas do milho, do sorgo e do milheto, além de trabalhar com outros temas como água, meio ambiente, agricultura familiar e agricultura orgânica. No final da década de 1980, a Embrapa Milho e Sorgo estimulou alguns produtores de sementes a se associar para a produção de sementes de milho híbrido gerado pela própria Embrapa, com base em cooperação mútua para levar esse material até a lavoura. Sem esse esforço, a Embrapa teria poucas 
oportunidades de difundir seus produtos no mercado junto com as transnacionais do setor, que têm seus próprios híbridos e, por isso, pouco interesse em divulgar a marca "BR" (Wilkinson \& Castelli, 2000).

Assim, em 1989, foi formada a Unimilho com 28 sementeiras associadas. Com sua formação, a Embrapa conseguiu levar a marca do milho híbrido BR 201 ao mercado, em um momento em que as empresas transnacionais concorriam com seus próprios híbridos. Com a boa aceitação de seu produto no mercado, a Embrapa conseguiu alterar a competitividade no mercado de milho, trazendo como resultado principal a baixa nos preços das sementes híbridas das transnacionais, além de influenciar a agenda de P\&D das empresas líderes nesse mercado. Como os híbridos da Embrapa tinham (e têm) adaptação especial aos solos ácidos e pobres dos cerrados, eles rapidamente alcançaram 15\% do mercado. Atualmente, a Unimilho é formada por 13 sementeiras $^{5}$ e possui menor participação de mercado (Santini, 2002; Wilkinson \& Castelli, 2000).

Carvalho (2003:140) discute as causas da concentração no segmento de milho híbrido no Brasil. Para o autor, a falta de políticas industrial e de proteção às empresas nacionais explica muito mais a situação encontrada no segmento de sementes de híbridos de milho do que a adoção de direitos de melhorista (a Lei de Proteção de Cultivares). "As estratégias de empresas internacionais se refletiram no Brasil na segunda metade da década de 1990 sem que as autoridades nacionais se contrapusessem estabelecendo politicas de defesa da concorrência e da indústria nacional".

Em meio a este processo, Martinelli (2004) aponta que quatro empresas multinacionais (Monsanto, Syngenta, Du Pont e Dow) dominam cerca de 90\% do mercado nacional de milho, enquanto a Embrapa, operando com a Unimilho, detém apenas $5 \%$ do mercado. Ainda segundo o autor, este é um segmento de mercado oligopolizado, formador de preços, com um processo produtivo caracterizado por elevada integração vertical. A competitividade neste segmento ocorre por diferenciação, sendo a qualidade da semente mais

\footnotetext{
5 As empresas que formam a Unimilho são as seguintes: Geneze Sementes (MG), Sementes Semel - Brasmilho (SP), Sementes Biomatrix (MG), Polato Sementes (MT), Sementes Selegrãos (SP), Sementes Talismã (GO), Sementes Fortuna - Brasmilho (MG), Planagri Sementes - Brasmilho (GO), Primaiz Sementes (MG), Sementes Semear Brasmilho (MG), Agromen Sementes (SP), Bonamigo Sementes (MS) e Sementes Gemma (MG). Informação obtida em www.unimilho.com.br. Acesso em 5/6/2006.
} 
importante que o seu custo. Por isso, a competição se assenta no constante lançamento de novos produtos atrelado à tecnologia de híbridos, que tem uma proteção biológica e, portanto, alta apropriabilidade.

Conforme Sousa et al. (1998), o mercado de sementes de milho pode ser divido em quatro segmentos com relação à tecnologia: i) de altíssima tecnologia, incluindo os híbridos simples ${ }^{6}$ de elevada produtividade e alguns triplos de alta produtividade; ii) de alta tecnologia (mas inferior ao do primeiro segmento), cujos produtos são os híbridos triplos com produtividade inferior ao simples e duplos de alta produtividade; iii) de tecnologia média, o qual engloba produtores com pouco recursos e dificuldade de acesso a inovações; e iv) de baixa tecnologia, cujos produtores possuem pouco controle sobre os seus fatores de produção e utilizam apenas variedades.

Dessa forma, no mercado de híbridos convivem grandes empresas ao lado de pequenas sementeiras. Estas últimas operam em segmentos e nichos de mercado de alcance local, regional e com especificidades, cujas características não interessam às empresas líderes (Wilkinson \& Castelli, 2000). A forma de atuação da Embrapa nesse mercado, por meio da Unimilho, permite que pequenos produtores continuem competindo, o que revela, diferente do que ocorre no mercado de sementes de soja, que a Instituição atende um público marginal que, de outra forma, estaria fora do mercado. Ou seja, enquanto IPPA a Embrapa executa sua função pública tanto no mercado de sementes de soja como no mercado de sementes de milho. Sua forma de atuação é diferente nesses mercados, refletindo as diferentes formas de organização características desses mercados, como acima foi assinalado.

\section{A proteção da propriedade intelectual no segmento de soja e milho híbrido}

A Lei de Proteção de Cultivares (LPC), promulgada em 1997, viabiliza a apropriação de inovaçóes e garante a propriedade intelectual sobre os cultivares, permitindo a cobrança de royalties e taxas tecnológicas. No segmento de soja,

6 Os híbridos se dividem em três categorias, conforme a forma como foram gerados, o que determina sua capacidade produtiva. O híbrido simples é o mais produtivo, mais caro e surge do cruzamento de duas linhagens geneticamente puras. Já o triplo é o resultado de encontro de três linhagens. O duplo nasce de quatro linhagens. Quanto maior o número de linhagens envolvidas, menor a sua produtividade. 
entende-se que a Lei favoreceu a onda de fusōes e aquisições ocorrida no final da década passada (Santini, 2002; Carvalho, 2003; Wilkinson \& Castelli, 2000).

Com base nas entrevistas realizadas (Fuck, 2005), especialmente em relação à soja, a parceria da Embrapa com outras instituiçôes de pesquisa era bastante ativa antes da instituição da LPC. À exceção das empresas estaduais que prosseguiram o trabalho de geração de cultivares de soja (as de Minas Gerais, Goiás e Rio Grande do Sul), em que a LPC exigiu uma maior formalização dos acordos que disciplinam a propriedade intelectual, nas demais inter-relações institucionais houve um declínio quase total da cooperação técnico-científica. O diagnóstico atual é de franca retração das relações de negócios entre todas as empresas do gênero, no que tange ao intercâmbio de informações e de germoplasma. Por outro lado, uma nova relação, que se estabeleceu após a instituição da LPC e em decorrência dela, foi aquela entre a Embrapa e o setor de produção de sementes, o qual passou a investir na geração de cultivares em troca da exclusividade de produção e comercialização das sementes durante determinado tempo.

No caso das variedades transgênicas (como a soja RR), a proteção ainda não foi definida no âmbito das leis de Propriedade Industrial e de Proteção de Cultivares. A própria cobrança de uma taxa tecnológica espelha essa situação. O que ocorre é uma expectativa de direito conjugado com um arranjo entre a Embrapa e a Monsanto; isso se fez pela impossibilidade de se cobrar royalties por patente sobre o microorganismo engenheirado. A legislação brasileira prevê patenteamento tão-somente para o OGM não encontrado na natureza, vedando a proteção para gene ou sequiência de genes. Assim, é a planta resultante de modificação decorrente da inserção de genes (o OGM é a planta) o objeto de proteção. Todavia, plantas não são matéria de proteção patentária no Brasil. Então, a proteção possível pela Lei de Propriedade Industrial é a inserção do gene na planta. Essa proteção oferece garantias de que será vedado ao produtor rural reproduzir sementes transgênicas sem autorização do seu titular, o que é permitido pela Lei de Proteção de Cultivares. Esta última protege a cultivar transformada em OGM (Carvalho, 2003). Então, a Embrapa fica com a parte legal (cobrança de royalties pela cultivar, o que está de acordo com a LPC) e a Monsanto monta acordos com os produtores para a cobrança de uma taxa tecnológica. 
Também é contemplado na Lei de Propriedade Industrial o licenciamento do gene para inserção em plantas de terceiros. Essa última estratégia é uma aposta que a Monsanto faz no mercado de soja. Sua estratégia é a de ter um produto próprio (variedade de soja de sua propriedade com o gene Roundup Ready) e ainda licenciar o processo de inserção para terceiros (Carvalho, 2003). Com isso, os produtores poderão escolher entre as cultivares desenvolvidas pela Monsanto ou aquelas desenvolvidas em parceria com a Embrapa ou com outras instituiçôes. ${ }^{7}$

Em relação aos atores envolvidos no mercado nacional de sementes de soja, os dados da safra 2000/01 revelam que os principais titulares de cultivares protegidas de soja foram as instituições públicas de pesquisa nacional (com 39\%), as empresas privadas estrangeiras $(38 \%)$ e as organizaçóes de produtores ou fundações a ela ligadas (20\%). As empresas nacionais e as universidades detiveram posiçôes marginais, participando com 1,5\% cada do total de cultivares protegidas (Embrapa, 2002). Neste cenário, a Embrapa foi o agente econômico de maior relevância na proteção de sementes protegidas de soja.

A análise do impacto da Lei de Proteção de Cultivares no segmento de sementes de soja mostra que de um lado houve redução da participação das empresas nacionais no mercado e ampliação das empresas multinacionais devido, principalmente, à compra do programa de soja da FT Sementes pela Monsanto, que resultou na formação da Monsoy. Por outro lado, há uma redefinição do espaço de intervenção pública, por meio das estruturas de pesquisas oficiais. Essa redefinição não implicou em perda de importância da pesquisa pública, pelo contrário, levou a uma nova forma de atuação. As articulações com parceiros tradicionais públicos passaram a ganhar uma mediação, que são as fundações, incisivamente presentes no segmento de soja (Carvalho, 2003).

"Essa articulação é responsável pela ampliação da participação da Embrapa na quantidade de cultivares utilizadas como sementes na safra 2000/01 em pouco mais de 50\%, em relação à participação individual da instituição federal. Em termos de quantidades de sementes produzidas, a participação

\footnotetext{
7 Além da Embrapa, a Monsanto possui acordo com outras importantes instituições de pesquisa no Brasil para desenvolvimento de variedades de soja resistentes ao glifosato, como a Coodetec, a Fundação Mato Grosso e a Fundação Centro de Experimentação e Pesquisa Fecotrigo (Fundacep Fecotrigo).
} 
da Embrapa ampliou-se em 78\%. E essa capilaridade é alcançada nas áreas de expansão e consolidação da cultura da soja, além de ganhar acesso a organização de produtores". (Carvalho, 2003:146)

No mercado de sementes de milho, a Embrapa também estabelece parcerias com a iniciativa privada para, entre outras coisas, ampliar sua participação no mercado. Contudo, o mercado de sementes de milho no Brasil apresenta características distintas, sobretudo quanto à forma de apropriabilidade e ao lançamento de novos produtos. As sementes de milho utilizadas no Brasil, sobretudo nas lavouras comerciais, são predominantemente de híbridos. $\mathrm{O}$ maior custo de produção decorrente da utilização de sementes de híbridos é compensado pela produção na colheita. Isso porque, o grão gerado por esse tipo de semente (o milho colhido pelo produtor) rende de $10 \%$ a $40 \%$ menos. $\mathrm{Ou}$ seja, o produtor sente-se obrigado a comprar a semente todo o ano. $\mathrm{O}$ mercado de híbridos é, então, o que dá mais espaço para inovações, sendo dominado pelo setor privado, com destaque para as empresas transnacionais. A proteção à propriedade intelectual desse tipo de cultivar é feita fundamentalmente por meio de segredo de linhagens (Carvalho \& Pessanha, 2001).

Carvalho (2003) ressalta duas importantes características do mercado de sementes de milho. A primeira delas é que as cultivares protegidas representam uma parcela reduzida do total de cultivares utilizadas como sementes. $\mathrm{O}$ total de cultivares protegidas utilizadas como sementes na safra 2000/2001 não alcançou os $3 \%$, enquanto a participação da produção de sementes originada de cultivares em questão foi de 0,6\%. A segunda característica diz respeito aos titulares das cultivares protegidas, sendo $90 \%$ instituições públicas de pesquisa e $10 \%$ de cooperativas de produtores agrícolas. Das cultivares que tiveram produção de sementes aprovadas, todas têm a Embrapa como titular. Ou seja, as empresas não protegem suas inovações em novas cultivares de milho pela LPC, visto que as cultivares de milho que tipicamente são utilizadas pelas empresas privadas são as híbridas, para as quais, a proteção mais efetiva é a propiciada pelo segredo ou informação não revelada (Carvalho, 2003).

Ainda segundo Carvalho (2003), esse é um contexto cuja alteração dependerá da incorporação de variedades transgênicas. Isso porque, embora a proteção para a inserção do gene se dê sob a égide as Lei de Propriedade 
Industrial, a cultivar que receberá o gene deve ser identificada e protegida. Assim, as estratégias das empresas líderes no segmento de híbridos de milho terão forte influência na decisão de utilização da proteção de cultivares.

Conforme Fuck (2005) (a partir de entrevistas realizadas), a Embrapa Milho e Sorgo está desenvolvendo pesquisas para a obtenção de milho geneticamente modificado com adaptacão a estresse abiótico (alumínio e fósforo), com melhor qualidade (metionina e lisina) e resistente a pragas (com Bt - Bacillus Thuringiensis - próprio). A expectativa é de que, no sistema de plantio direto, os produtores utilizem o milho transgênico resistente à herbicida, dado que ele poderá ser mais vantajoso. No caso de pragas, a principal é a lagarta do cartucho (Spodoptera frugiperda), seguida do elasmo (Elasmopalpus lignosellus) Como essas pragas não são importantes no hemisfério norte, os Bt's importados podem não ter tanta efetividade para o controle da lagarta do cartucho. Ao mesmo tempo, essa praga tem, atualmente, resistência a uma série de inseticidas e pode também ter resistência para o transgênico. Assim, o manejo de pragas vai também ser muito importante. A adoção do OGM vai ser maior em áreas de maior ocorrência da praga e onde os problemas mencionados são maiores.

Carvalho (2003) também ressalta que o processo de concentração verificado no segmento de sementes de milho híbrido não deve ser confundido como decorrente do processo de reconhecimento de direitos de proteção de cultivares no Brasil. $\mathrm{O}$ fato desse processo de concentração ter ocorrido concomitantemente à implantação da legislação de proteção às inovações em plantas, ao final dos anos 1990, não estabelece uma relação de causa e efeito. Entende-se que a concentração ocorreu devido às características do próprio mercado e pela estratégia das empresas líderes, e não devido à mudança institucional.

\section{A relação Embrapa/Monsanto}

A Monsanto foi a pioneira no segmento de mercado de produtos geneticamente modificados, ao desenvolver uma linha de sementes transgênicas, com destaque para a RR, uma semente de soja com maior resistência ao principal produto da empresa, o herbicida Roundup, a base de glifosato. Conforme apontado por Santini (2002), a entrada da Monsanto no segmento de milho no Brasil ocorreu em 1997, com a compra da Agroceres. No caso da soja, a 
entrada da empresa no mercado de sementes de variedades também ocorreu em 1997, com a aquisição da FT Sementes. Tal aquisição foi parte das estratégias da Monsanto em ganhar mercado na área de sementes, após os pesados investimentos em P\&D de biotecnologia.

Conforme Lazzarini e Nunes (1998), este fato reforça a idéia de que os elevados montantes de recursos envolvidos no processo de P\&D em genética, especialmente com a crescente importância do uso de biotecnologia, deve induzir naturalmente uma maior concentração na indústria de sementes. Até mesmo empresas públicas deverão readequar seu processo de inovação tecnológica de forma a acompanhar a nova dinâmica do mercado com os elevados investimentos trazidos por empresas privadas.

No caso da soja RR, existe um acordo de cooperação técnica firmado entre a Embrapa e a Monsanto em 1997. Por meio desse contrato, a Embrapa obteve suporte legal para conduzir pesquisa de avaliação de eficiência do gene e da construção gênica da soja resistente ao herbicida à base de glifosato e concluiu que essas tecnologias da Monsanto são eficientes tecnicamente. Com base nos resultados obtidos, a Embrapa decidiu desenvolver cultivares de soja transgênica resistentes à herbicida a base de glifosato, que seriam protegidas em nome exclusivo da Embrapa. Em março de 2000, após a cooperação técnica entre as duas empresas, foi assinado o contrato comercial que possibilitaria à Embrapa colocar no mercado as suas cultivares de soja transgênica. Entre outros, seria necessário que os parceiros indicados pela Embrapa assinassem com a Monsanto um contrato para uso comercial da tecnologia Monsanto. De modo semelhante ao de soja convencional, o projeto de desenvolvimento de cultivares de soja transgênica deveria ser realizado em parceria com produtores de sementes e fundaçóes. Com fundamento na LPC, todas as cultivares transgênicas obtidas pela Embrapa seriam protegidas exclusivamente em seu nome. ${ }^{8}$

Por outro lado, a tecnologia da Monsanto já está protegida em seu nome no Brasil com fundamento na Lei de Propriedade Industrial. Os produtores de semente licenciados individualmente pela Embrapa, após assinarem o contrato com a Monsanto, pagariam royalties à Embrapa pelo uso da cultivar protegida em seu nome. A Monsanto receberia dos produtores de sementes

8 Informação obtida em www.embrapa.gov.br. Acesso em 25.8.2003. 
parceiros da Embrapa uma taxa pelo uso de sua tecnologia. Essa taxa tecnológica é um acordo, não um licenciamento clássico. Esse acordo é importante, para os produtores, especialmente para a soja exportada, já que a Monsanto pode embargá-la nos portos de destino, alegando infração de direitos.

O valor dessa taxa é negociado entre os produtores de sementes e a Monsanto. Os produtores de soja que usassem as variedades transgênicas desenvolvidas pela Embrapa poderiam usar qualquer herbicida cujo princípio ativo seja o glifosato, hoje de domínio público, ${ }^{9}$ desde que o produto seja registrado no Ministério da Agricultura, Pecuária e Abastecimento. Vale destacar que as duas empresas mantêm a sua completa autonomia. $\mathrm{O}$ interesse da Monsanto reside na possibilidade de um aumento da venda do herbicida Roundup - na medida em que sejam produzidos cultivares resistentes - e no recebimento da taxa tecnológica. A Embrapa, por sua vez, teve acesso ao gene RR de propriedade da Monsanto (a Embrapa considerou imprescindível também participar da oferta dessa tecnologia).

Em meio a este ambiente de parcerias institucionais, Carvalho (2003) ressalta a importância dos mecanismos de proteção ao analisar o processo de co-evolução entre as estruturas institucionais, as estratégias dos agentes econômicos e os processos de coordenação organizacional. As trajetórias dos principais agentes (pesquisa pública, empresa multinacional e organização de produtores rurais) são complementares e articuladas num ambiente altamente competitivo. Neste sentido, a expansão da Monsanto no segmento de sementes de soja no Brasil não desaguou num processo de desnacionalização. Isso foi possível em decorrência do processo de coordenação da pesquisa pública no segmento em questão, assim como da presença de organização de produtores. Mesmo com a forte presença da Monsanto no mercado, a presença majoritária é ocupada pela Embrapa, individualmente e para o conjunto de seus parceiros, o que confirma a hipótese defendida pelo autor de que os mecanismos de proteção à propriedade intelectual são fundamentais para a organização e coordenação da pesquisa agropecuária e podem fortalecer a institucionalidade da pesquisa pública e não o contrário.

9 Segundo Kageyama et al. (1990), citados por Carvalho (2003), o glifosato, princípio ativo do herbicida cuja patente era da Monsanto, foi, em determinado momento, nacionalizado pela empresa Nortox. A Monsanto perdeu os direitos sobre o produto por não ter cumprido o prazo de três anos concedido pelo INPI para produzi-lo no Brasil. A legislação da época punia com a perda dos direitos proprietários a não exploração da patente. 
Acredita-se que houve um ganho na efetividade da atuação da Embrapa, a partir das relações que estabelece com outros atores do ambiente do agronegócio (Monsanto, fundações de produtores, institutos de pesquisa estaduais, etc.) e isso permite o cumprimento de sua função pública. A partir disso, havendo uma melhor interação com os demais atores, as açōes da Embrapa como IPPA são fortalecidas, melhorando sua atuação no mercado de sementes de soja.

\section{A relação Embrapa/Unimilho}

Para competir no mercado de sementes de milho, as empresas nacionais médias e pequenas dependeram, em grande medida, das IPPAs, responsáveis pela tecnologia gerada na produção dos milhos híbridos. Conforme mostra Machado Filho (1995), o IAC (Instituto Agronômico) foi a instituição que originou os primeiros híbridos, no início da década de 1970. Contudo, ao longo daquela década, o IAC não conseguiu acompanhar o mesmo ritmo de pesquisas das empresas privadas. Neste período, a participação no mercado de sementes públicas caiu de $20 \%$ para $5 \%$ do mercado, gerando com isto a própria inviabilização das pequenas e médias empresas produtoras de atuarem em um mercado altamente competitivo. Ainda segundo o autor, de um número de aproximadamente 30 empresas produtoras que se utilizavam do híbrido do IAC, sobreviveram apenas três empresas de porte médio. Estas empresas, juntamente com outras 14 empresas clientes da Embrapa como compradoras de sementes básicas de outros produtos, desejosas de entrarem no ramo da produção de milhos híbridos passaram a exercer pressão junto ao CNPMS no sentido deste lançar híbridos de milho no mercado.

Como dito, a Unimilho foi criada em 1989 com o apoio da Embrapa. A parceria Embrapa e Unimilho é exemplo de sucesso e já foi reconhecida pelo Banco Mundial como a integração pública e privada modelo a ser seguida pelos países em desenvolvimento (www.unimilho.com.br, acesso em 5/6/2006). São vários os benefícios decorrentes de sua formação. Conforme sintetiza Machado-Filho (1995), a Embrapa cumpre suas funções de gerar e difundir tecnologia, oferecendo produtos de pesquisa, além de gerar recursos para as suas atividades, diminuindo a dependência de recursos públicos. 
Desenvolve também a capacitação nacional em termos de pesquisa em melhoramento de milho em ambiente tropical, podendo ainda exportar esta tecnologia para outros países. Os franqueados (as empresas sementeiras que compõem a Unimilho) se beneficiam do sistema na medida em que se torna viável a participação no segmento de mercado de sementes melhoradas, que seria impossível de outra forma, pela alta competitividade do setor e os altos investimentos em pesquisa. $\mathrm{O}$ autor destaca o suporte dado pela equipe multidisciplinar de pesquisadores e técnicos da Embrapa, com a conseqüente transferência de capacitação técnica, além do suporte em termos mercadológicos oferecido pela Unimilho.

Já os produtores de milho se beneficiam por poderem se utilizar de sementes melhoradas a um custo relativamente baixo, tendo com isto um upgrading tecnológico. A principal evidência para tanto é a velocidade e área de abrangência com que o produto BR foi adotado pelos agricultores, atingindo ao mesmo tempo toda a região produtora para a qual tal produto foi recomendado. Sem a formação da Unimilho, a Embrapa não teria condições de difundir de maneira tão ampla seus produtos, para benefício final dos agricultores. Por outro lado, os franqueados não teriam condições técnicas e financeiras de atuarem num mercado fortemente concentrado, dominado por grandes empresas (Machado-Filho, 1995:19).

A Unimilho concentra suas operaçōes em cinco Estados, sendo eles: Minas Gerais, São Paulo, Goiás, Mato Grosso e Mato Grosso do Sul. Dadas as características do milho híbrido que comercializa (grande adaptabilidade aos Cerrados), os Estados de Minas Gerais e Goiás ganham relevância. Para a Embrapa, interessa a maior cobertura geográfica e capilaridade das redes de comercialização e distribuição possíveis, justamente para evitar a competição entre os licenciados. Essas redes de distribuição, comercialização e assistência técnica são vantagens competitivas importantes para a Unimilho. Essa importância deriva do caráter local/regional das empresas associadas, o que lhes permite trabalhar de forma diferenciada, em função de cada região e do tipo de clientela a que serve. A localização das Unidades Beneficiadoras de Sementes também é considerada vantagem importante, pois se encontram na área de expansão de cada empresa associada (Carvalho, 1996). O mesmo autor destaca que o licenciamento não deve ser visto apenas do ponto de vista do produto em si, mas ainda do acesso à $\mathrm{P} \& \mathrm{D}$ levado a termo na Embrapa. 
A formação da Unimilho permitiu à Embrapa intervir no mercado de sementes e, com isso, evitar que o mesmo fosse totalmente dominado por empresas transnacionais. Para que a Embrapa continue atuante neste mercado (e também em outros), entende-se que as mudanças em curso na direção da Instituição devem priorizar uma maior capacitação em novas tecnologias (na biotecnologia, em especial) e uma maior interação com o setor privado.

\section{Conclusão}

A nova forma de organização da pesquisa agrícola impõem um comportamento estratégico às IPPAs. $\mathrm{O}$ avanço do setor privado nas pesquisas em biotecnologia e, em muitos casos, a fragilização financeira do setor público dos países em desenvolvimento têm determinado uma queda na importância das IPPAs no desenvolvimento de novas cultivares (em relação ao papel ocupado na época da Revolução Verde). Porém, entende-se que, sem o fortalecimento das IPPAs, os países em desenvolvimento podem não aproveitar as possibilidades a serem exploradas com a biotecnologia.

No caso brasileiro, a atuação da Embrapa tem sido um bom exemplo da forma como uma IPPAs pode conduzir pesquisas com biotecnologia, articulando-se com o setor privado no processo de pesquisa e no mercado de sementes. No caso do mercado de sementes de soja, a Embrapa, a partir do acordo com a Monsanto, pode ofertar sementes de soja RR, que nos últimos anos vinham sendo bastante demandadas pelos produtores brasileiros (via importação ilegal de sementes trazidas da Argentina). No caso do mercado de sementes de milho, a formação da Unimilho permitiu à Instituição intervir no mercado de sementes e, com isso, evitar que o mesmo fosse totalmente dominado por empresas multinacionais.

As discussões aqui realizadas sobre o ambiente da organização da pesquisa e dos mercados em soja e em milho híbrido revelam que uma IPPA pode executar suas funçôes públicas de diversas maneiras. Antes da LPC, a Embrapa manteve-se hegemônica no mercado de soja na ausência de direito de propriedade, exercendo sua função pública ao cobrar um preço baixo pela semente produzida e ao desenvolver novas variedades para atender diferentes regiôes produtoras. Quando ocorreu a mudança no regime de propriedade, houve mudança também na percepção da Embrapa em relação ao seu papel no mercado de sementes. 
A instituição passa a considerar estrategicamente seu portfolio de sementes como um ativo, que é valorizado por meio da cobrança de royalties, e passa a formular acordos que preservam sua função pública e mantêm seus ativos (banco de germoplasma) em seu poder. A partir disso, e tendo uma visão estratégica de como exercer sua função pública, a Instituição estabelece parcerias com empresas multinacionais (como a Monsanto) e com fundações de produtores, visando o desenvolvimento de novas cultivares e a sua própria permanência na condição de líder nesse mercado de sementes. Não é demais ressaltar que esse modelo de parcerias da Embrapa tem sido fundamental para o desenvolvimento de germoplasma adaptado às condições tropicais, o que tornou possível o plantio da soja em diversas regiōes produtoras do Brasil. A oferta de novos cultivares desenvolvidos através das parcerias da Embrapa foi acompanhada pela incorporação de resistência às principais doenças que atacam a cultura no País, assim como de genes para resistência aos herbicidas Glifosato e Imidazolinonas (Embrapa, 2004).

No mercado de sementes de milho, tradicionalmente dominado pela iniciativa privada devido à maior apropriabilidade do esforço inovativo, a LPC, justamente por isso, não teve papel tão significativo. Contudo, nos últimos anos, houve profunda desnacionalização das empresas que compõem o setor. Nesse momento de acirramento da concorrência, as empresas nacionais organizadas em torno da Unimilho podem se favorecer da tecnologia desenvolvida pela Embrapa e, com isso, permanecer competitivas, mesmo que seja atuando em segmentos marginais do mercado. Neste caso, mais do que uma estratégia puramente competitiva, a atuação da Embrapa é necessária para o atendimento de pequenos produtores e, também, para que esse segmento não seja totalmente dominado por empresas multinacionais - apesar de atualmente a participação da Unimilho não ser tão significativa no mercado. Além disso, o desenvolvimento de variedades transgênicas de milho por parte da Embrapa pode ter boa aceitação entre os produtores, o que pode favorecer a ampliação de mercado por parte da Unimilho e, também, ofertar aos produtores cultivares de melhor desempenho.

A partir do conhecimento das especificidades do mercado nacional de soja e milho (estrutura oligopolizada, forte presença de organização de produtores, complementaridade de proteção jurídica para os OGMs, segredo de 
linhagens parentais no mercado de híbridos, etc.) e de suas competências essenciais, a Embrapa pode melhor intervir e se relacionar com os demais atores envolvidos no processo inovativo em questão. Essa nova forma de atuação da Embrapa favorece a obtenção de economias de escala em P\&D, dividindo riscos e explorando a complementaridade de ativos e ainda obtendo economias de escopo.

Nos casos analisados neste artigo, entende-se que a relação entre a Embrapa e as fundações possibilita ampliar, dinamizar e refinar o programa de melhoramento genético da Instituição, permitindo a recomendação mais segura de um maior número e de melhores cultivares, além de agilizar o processo de transferência desses novos materiais aos produtores interessados. Com isso, novas cultivares são testadas a cada ano em mais de 100 locais, em diferentes regiōes do País (Dall'Agnol, 2004). No caso da soja resistente ao herbicida à base de glifosato, a Embrapa considerou importante também participar da oferta deste tipo de cultivar, o que a levou a fazer um acordo com a Monsanto (que já tinha protegido sua tecnologia no Brasil). No caso do mercado de milho híbrido, a atuação da Embrapa, via Unimilho, amplia a concorrência nesse mercado e possibilita que as pequenas empresas sementeiras permaneçam competitivas.

ENDEREÇOS PARA CORRESPONDÊNCIA:

Marcos Paulo Fuck - fuck@ige.unicamp.br

Rua João Pandiá Calógeras, 51 - Barão Geraldo - C.P. 6152 - Campinas, SP - 13083-970

Maria Beatriz Bonacelli - bia@ige.unicamp.br

IG/UNICAMP - sala 3 - Barão Geraldo - C.P. 6152 - Campinas, SP - 13083-970 


\section{Referências bibliográficas}

Beintema, N.M. ; Avila, A.F.D. ; Pardey, P.G., P\&G Agropecuário : Política, Investimentos e Desenvolvimento Institucional, Washington, DC: IFPRI, Embrapa e Fontagro, ago., 2001

Bonny, S.; Daucé, P. "Les nouvelles technologies en agriculture", in Cahiers d'Économie et Sociologie Rurales, n.13, p.5-33, 1989.

Carvalho, S.M.P.; Pessanha, L.D.R., "Propriedade intelectual, estratégias empresariais e mecanismos de apropriação do esforço de inovação no mercado brasileiro de sementes", in Revista de Economia Contemporânea, 5 (1), p.51-182, jan./jun., 2001.

Carvalho, S.M.P., "A importância da superação do paradigma produtivista pelos sistemas estaduais de pesquisa", in Cadernos de Ciência e Tecnologia, v.13, n.1, p.21-42, 1996.

, Propriedade intelectual na agricultura. Tese de doutorado. Departamento de Política Científica e Tecnológica (DPCT), Instituto de Geociências (IG), Universidade Estadual de Campinas (Unicamp), Campinas, 2003.

Dal Poz, M.E.; Silveira, J.M.; Fonseca, M., "Direitos em Propriedade Intelectual em Biotecnologia: um processo em construção", in Biotecnologia e recursos genéticos: desafios e oportunidades para o Brasil, Campinas: Instituto de Economia/FINEP, 2004.

Dall'Agnol, A., A Embrapa e a parceria público-privada (PPP), disponível em http:/ www.agrolink.com.br/colunistas (15.8.2004), 2004.

Embrapa - Empresa Brasileira de Pesquisa Agropecuária, A Produção de Sementes no Brasil: relatório da safra 2000/2001, Brasília: Embrapa/Ministério da Agricultura, Pecuária e Abastecimento/Abrasem, 2002.

, Relatório de gestão 2003 (Embrapa soja), disponível em http:// www.cnpso.embrapa.br (15.8.2004), 2004.

FAO - Organização das Nações Unidas para Agricultura e Alimentação. El estado mundial de agricultura y la alimentación. La biotecnologia agrícola: ¿Una respuesta a las necesidades de los pobres?, Roma, 2004.

Fuck, M.P., Funçôes Públicas e arranjos institucionais: o papel da Embrapa na organização da pesquisa de soja e milho híbrido no Brasil. Dissertação de Mestrado. 
Departamento de Política Científica e Tecnológica (DPCT), Instituto de Geociências (IG), Universidade Estadual de Campinas (Unicamp). Campinas, 2005.

Hayami, Y.; Ruttan, V., Desenvolvimento agricola: teoria e experiências internacionais. Embrapa, Brasília, 1988.

James, C., "Executive Summary of Global Status of Commercialized Biotech/GM Crops: 2005", in ISAAA Briefs N. 34, ISAAA: Ithaca, NY., 2005.

Lazzarini, S.G., Nunes, R. "Competitividade do sistema agroindustrial da soja”, in Elizabeth Maria Mercier Qurido Farina; Decio Zylbersztajn. (orgs.), Competitividade no Agribusiness Brasileiro, v.5, p.194-420, Pensa/FEA/USP: São Paulo, 1998.

Machado-Filho, C.A.P. Embrapa: franquia em genética vegetal - novas modalidades de transferência de tecnologia. PENSA/USP, 1995.

Martinelli, O. Relatório setorial preliminar: setor sementes. Diretório da Pesquisa Privada (DPP), disponível em http:/www.finep.gov.br/portaldpp (15.6.2006), 2006.

Massola, M.P., A organização da pesquisa agrícola privada cooperativa: um estudo de caso da Coodetec. Dissertação de Mestrado. Departamento de Política Científica e Tecnológica (DPCT), Instituto de Geociências (IG), Universidade Estadual de Campinas (Unicamp), Campinas, 2002.

Mello, D., Tendências de reorganização institucional da pesquisa agrícola: o caso do instituto agronômico do Paraná (IAPAR). Dissertação de Mestrado. Departamento de Política Científica e Tecnológica (DPCT), Instituto de Geociências (IG), Universidade Estadual de Campinas (Unicamp), Campinas, 1995.

Petit, M.; Barghouti, S., "Diversification: Challenges and Opportunities", in Trends in Agricultural Diversification: Regional Perspectives. World Bank, Technical Paper 180. Washington, D.C., 1992.

Piñeiro, M.; Trigo, E., Latin american agricultural research. The public sector: problems and perspectives. The Hague, Netherlands: ISNAR, 1985 (Working paper n. 1).

Ruttan, V., Agricultural Research Policy, Minneapolis: University of Minnesota Press, 1983. 
Salles-Filho, S.L.M., A dinâmica tecnológica da agricultura: perspectivas da biotecnologia. Tese de Doutoramento. Instituto de Economia (IE), Universidade Estadual de Campinas (Unicamp), Campinas, 1993.

"Integração de mercados e privatização da pesquisa: impactos sobre a estrutura e a dinâmica organizacional dos INIAs", in Schneider, J.; Gomes, J.; Nunes, L. (orgs.) Integração de mercados e desafios para a pesquisa agropecuária - Mercosul e União Européia. Embrapa/CPACT \& Procisur: Pelotas, 1995.

Salles-Filho, S.L.M.; Albuquerque, R.; Mello, D. "Novos Rumos da Pesquisa Agrícola e Agroindustrial” in Almeida, J.; Navarro, Z.. (orgs.). Reconstruindo a Agricultura. $1^{a}$ ed. Porto Alegre, p.189-203, 1997.

Santini, G., A reestruturação da indústria de sementes no Brasil: o novo ambiente concorrencial dos segmentos de milho híbrido e soja. Dissertação de mestrado. Departamento de Engenharia de Produção. (DEP), Universidade Federal de São Carlos (UfSCar). São Carlos, 2002.

Santini, G.; Paulillo, L.F., "Mudanças tecnológicas e institucionais na indústria de sementes no Brasil: uma análise aplicada aos mercados de milho híbrido e soja”, in Agricultura em São Paulo, 50 (1): 25-42, 2003.

Scatolin, F.; Meirelles, G.; Paula, N., "Arranjo produtivo local - o caso da soja no Paraná”. Arranjos Produtivos do Complexo Soja Paranaense. Projeto de Pesquisa: Arranjos e Sistemas Produtivos Locais e as Novas Políticas de Desenvolvimento Industrial e Tecnológico. Estudos Empíricos. Nota Técnica 19. Instituto de Economia da Universidade Federal do Rio de Janeiro - IE/UFRJ, 2000.

Schultz, T., A transformação da agricultura tradicional, Rio de Janeiro: Ed. Zahar, 1965.

Seiler, A., "Biotecnologia e Terceiro Mundo: interesses econômicos, opções técnicas e impactos socioeconômico", in Araújo, H. (org.), Tecnociência e Cultura ensaios sobre o tempo presente, São Paulo: Estação Liberdade, 1998.

Silveira, J.M.F.J. da; Salles-Filho, S., A entrada do grupo Monsanto na indústria de sementes no Brasil: algumas consideraçôes sobre os impactos sobre a concorrência. Campinas: Unicamp, Instituto de Economia, 1998.

Silveira, J.M.F.J. da, Progresso técnico e oligopólio: as especificidades da indístria de sementes no Brasil. Instituto de Economia (IE), Universidade Estadual de Campinas (Unicamp). Campinas, 1985.

Sousa, E.L.L.; Azevedo, P.F.; Saes, M.S., "Competitividade do sistema agroindustrial 
de milho" in Elizabeth Maria Mercier Qurido Farina; Decio Zylbersztajn. (org.). Competitividade no Agribusiness Brasileiro. Pensa/FEA/USP, São Paulo, v.2, p.273432, 1998.

Traxler, G., The economics impacts of biotechnology - based technological innovations. Agricultural and economics development analysis division, FAO, ESA, texto para discussão, n.3, jul., 2003, disponível em http:/www.fao.org/es/esa (15.8.2004).

Trigo, E.; Piñero, M.; Ardila, J., Organización de la investigación agropecuaria en América Latina, San José, Costa Rica: IICA, p.537, 1985.

Wilkinson, J.; Castelli, P., A transnacionalização da indústria de sementes no Brasil biotecnologias, patentes e biodiversidade. Rio de janeiro: ActionAid, Brasil, 2000. 